\title{
The legacy of Nils Christie
}

\section{Glimpses into the authorship of a giant}

Nicolay B. Johansen

This essay is based on an oral presentation at the seminar "Crime control and punishment - Georgian and Norwegian perspectives

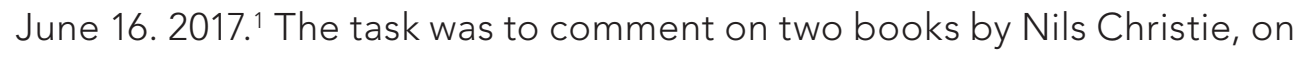
the occasion that they were translated into Georgian.

\section{Introduction}

Christie was a giant. He was a Big Friendly Giant, as in Roald Dahls famous novel »BFG« (Dahl 2007). He was a giant in life, both as a person and as an author (Halvorsen 2014). He consequently argued for a dramatic reduction in punishment and comes close to arguing for the abolition of prisons (Mathiesen 2016). His books and articles convey an optimistic image of mankind, and they are written in an unusually accessible language. His works were translated into numerous languages and he was especially eager to travel in the former eastern block.

Christie's works are written in a Scandinavian context. It focuses on the handling of outsiders in a welfare state where the rule of law is more or less taken for granted. This is a different context from post-soviet familial societies like Georgia. None-the-less, they may convey discussions of profound dilemmas and paradoxes in all aspiring democracies.

\section{Christie's project}

Christie was trained as a sociologist in Oslo, in post-war Norway. My belief is that his way of thinking sociologically was informed by his view on the Great War and its atrocities. The Great War formed his sociology and his academic project.

His personal and academic project can be found in the programmatic ending of his first book. In 1952 he published his master thesis as a book that is by now included in an authoritative list of the most important sociological works

1. Set up by the Georgian-Norwegian Rule of Law association. 
in Norway (Christie 1972). His first scientific endeavour was a study of guards

in camps for prisoners of war, the so-called »serb-camps« in the northern parts of Norway. On par with the cruelties on the continent, prisoners in the serb-camps were treated inhumanly and many were killed. Christie wanted to know why some guards did get involved in cruel behaviour and others did not. His conclusion was that guards who saw the prisoners as more than prisoners, those who rather looked at them as human beings and persons, did not get involved in cruelties. A common characteristic for those who committed cruelties was that they regarded the prisoners as subhuman.

One of the fundamental ways to see the prisoners as persons was to talk to them. Seeing them as persons, with hopes and views, projects and ambitions, made the threshold for cruelties higher. Christie's interpretation was that language was one of many barriers for the guards to view the prisoners as human beings like themselves. The moral lesson was that to avoid cruelty one must, in his friend Baumans (1989) later terms, facilitate a form of social visibility and reduce social distance.

This way, social proximity attracted Christies attention. And although he rarely used the concept himself, I contend that this became the core theme in his entire authorship (see also Christie 1982b). The proximity thesis connects his sociology with his academic project, born out of the post-war experience. His final words in his first book was that everything comes down to preventing that Holocaust is repeated.

»The most pressing question in our time is to prevent it from happening again« (Christie 1972/1952).

»|t« here, is the Holocaust. In the following, I will present two comments to Christie's authorship.

Firstly, I believe that this was the credo of his entire life's work and the key to understand his books. His career was within the field on penology and criminology, thus his attention was primarily directed at penal institutions, but the scope of his work was broader.

Secondly, his contribution to prevent a Holocaust from happening again was to insist on a sociology that emphasized social proximity. By presenting the two books that are now published in Georgian, I will outline some key elements in his sociology.

\section{Limits to pain}

"Limits to pain « (Limits) summarizes one of the core dilemmas in modern societies. This dilemma is presented on the very first pages of the book. The starting point is that the basic thing with punishment is that it delivers pain: 
»imposing punishment within the institution of law means the inflicting of pain, intended as pain« (Christie 2007, page 5).

This is the naked fact about punishment. Behind every good reason for punishing, behind every benefit associated with penal measures, lies the element of pain. Christie did not come to this insight all by himself; it has been acknowledged by penal theorists since the second part of the $18^{\text {th }}$ century (Flaatten 2014). Still, it is rarely discussed in its naked form. Christie follows up with contrasting punishment as pain with the universal virtue of doing good.

»This is an activity which often comes in dissonance to esteemed values such as kindness and forgiveness « (Christie 2007, page 5).

The dilemma is that societies inflict pain despite the virtue of doing good. To handle this dilemma the true nature of punishment is shadowed, and when it proves insufficient to hide it, it is justified with a number of fanciful theories. The book is an attempt to strip the attempts to hide the core features of punishment and to dismantle its main justifications.

First, he addresses how words are chosen to make punishment look prettier. However, the main bulk of his text revolves around the subject of justifications. The phrase "Justifications of punishments implies that the impulse to punish lies at the bottom. Punishment is there as a constant fact. The thing that changes is its justifications.

Christie discusses two main trends in justifications of punishment, General deterrence and special prevention. In western countries, general deterrence is associated with the $19^{\text {th }}$ century and special prevention with the 20 century.

Christie's main concern was the ideology of special prevention and »treatment" in his day. He had embarked on a mission to fight punishment in the guise of treatment 25 years before the publication of Limits to pain. As a young man he had taken up the injustices experienced by drunkards and vagabonds encountering the penal system (for a presentation of this story in English, see Hauge 2007). Christie led a group of vocal sociologist and critical legal scholars who criticized the foundations of the severe sanctions given to people from the lumpen proletariat. Young offenders were handled similarly. They were given more severe sentences, judged by the length of mandatory stays in institutions, than if they had been found guilty of ordinary crimes. People found needing special treatment were given non-specified sentences. All of these instances were justified by reference to the new sciences and their optimistic view that their conditions could be cured. Psychology, psychiatry, labour training and schooling, not to mention strict discipline, should put deviants on the right track.

Christie refers to research that characterizes this ideology as a chimera. First, the sciences did not deliver the results they promised. Secondly, by all practical measures reality in the institutions were similar to prisons. The 
ideology of special prevention justified harsher treatment of poor people than they would otherwise be subjected to.

Christie was optimistic about reducing the impact of the ideology of special prevention. When he wrote Limits he had won almost all his battles. His group had managed to remove the legislation that locked up drunkards and vagabonds for loitering (Hauge 2007). Furthermore he had almost won a battle to eliminate the use of special institutions for those found weak and cognitively »immature«. On an optimistic note he described the situation as »The fall of an empire« (Christie 1978). At this stage of his career Christie had fought long and hard political battles, but all of them had ended in victories or near-victories. He also had the attention of the political elites.

However, Christie was concerned that classical ideals of general prevention/ deterrence was on the rise. He observed that legal scholars would sneak in and give enthusiastic lectures on behalf of the ideas of how punishment could prevent crimes by evoking fear of being caught by the police and judged by courts. The classical ways of justifying punishment was on the rise. Christie addressed this line of justification and argued that it is 1) unethical, and 2) that it does not produce the results it promises. And of course, it legitimizes increased used of punishments.

Christie's concern did not solely relate to the rise of general prevention as a way to legitimize punishment. He also observed an emerging trend that court decisions were being stripped of its »human « factor, the judge's discretion. The judge is in a position where he can moderate the faceless criteria's for punishment with the person actually appearing before the court. The judge's discretion gives room for the human factor, to relate to the person accused, to see him (or her) as more than his bad act. Christie feared the reduced role of the judge in the emerging regime of sentencing tables.

The reason general deterrence and special prevention is accepted as justifications for punishment is that we as states and societies are all too ready to accept stories that cover up the inherent dilemma in modern societies. As members of society we are all suffering from a tension following the dilemma concerning punishment. The theories of justification offer an ailment for this tension. As a corollary, these theories facilitate more pain delivery.

Christie's book is openly normative. He labels himself as a »moral imperialist«. His imperialism centres on the ideas that we should stop using punishment, and as a secondary stance, use it a little as possible. In the final chapters he draws up a sketch of the social conditions required for reducing the level of punishment.

1. The first requirement is to facilitate $» k n o w l e d g e$. In social webs where people become acquainted with each on more planes, they come to »know" each other in more capacities than one. When persons are visible for each other as more than roles and acts, this makes the threshold for inflicting pain higher. We should strive for more »close knit societies«- 
2. One should strive to reduce differences in power between members of a society. People with power are more likely to inflict pain on others.

3. It is important that people in position to inflict punishment are vulnerable. They must be vulnerable to control by their peers.

4. A social structure in which members are mutually depending on each other also lifts the threshold for punishment. Thus Christie advocates policies on a broad level that enhances smaller communities. He is critical of the developments he observed, centralization, urbanization and differentiation of work. His view of the "good society« is modelled on the village.

Together these four elements constitute his »sociology of proximity«. The sociology of proximity amounts to a theory that a society characterized by social distance is both a society in which people do not thrive and that it facilitates high levels of punishment.

In the final chapter he develops these ideas with particular focus on alternative ways to resolve conflicts. The chapter called "participatory justice» he draws up the main principles within the movement that has later become famous as »Restorative justice«. He wrote down his thinking on how so-called conflicts could be transferred back to the persons involved in a small article (Christie 1977). The title of this article was "Conflict as property" and it condensed his way of thinking. The article inspired people to establish alternative channels for resolutions to problems arising out of crime. Offenders were invited to meet the victims of their acts and the parties were guided to find a way to move forward after the incident. This way of handling "conflicts « soon proved to be more satisfying for both victims and perpetrators, especially in cases of small scale incidents. Experiments with "alternative conflict resolution « started in a small community in Norway in 1980 and was gradually implemented nationwide. Other countries adopted the same ideas and it soon became a global phenomenon.

Such is the impact of Christie, and this is not the only footprint he left on the planet. It speaks volumes of Christie's achievements that this movement only forms a fragment of this book. But it should be remembered that the mentioned list of requirements for a society with little punishment offers some of the basic sociological views that underpins his entire project, both as an academic and political entrepreneur.

\section{Crime control as Industry}

Limits was an early warning of what was about to come. The international literature in criminology from the mid 90 -ies revolved around the increasing levels of prison rates and punishment. In "Crime control as industry - toward Gulags, western style« (Crime control), Christie foresaw this development. 
Furthermore, his analysis anticipated the major trends in analysis of this in-

crease.»

Whereas Limits is concerned with the Nordic context, Crime control has an international and global scope. As the subtitle indicates, it contrasts the western and eastern hemispheres. He raises the question of whether the increasing prison population in United States does not put them on par with the admittedly totalitarian counterpart in former Soviet Union. Rhetorically, this is a tough accusation.

Sociologically the conflation of the former superpowers questions how smaller states relate to the more dominant ones. In Limits Christie emphasizes the examples of Finland and Netherlands to argue that levels of punishments are results of political choices and local cultures. He demonstrates that the low levels of prison rates in these countries are results of conscious choices of what kind of penal cultures they wanted to be and belong to.

Crime control develops this argument and brings it to a new level. Here Christie embarks on two ways of thinking I will comment on.

1. He invented a discipline he called "penal geography«. Penal geography is the name of comparing prison rates. Comparing prison rates is not as straight forward as one might think, but yet again his work resulted in a movement. Today penal geography is institutionalized by the organization Prison watch and The Prison Brief. His endeavours in penal geography support his argument, that levels of punishment are not destiny, but a result of choices:

2. In Crime control prison rates are not merely seen as a matter of culture and choice; they are influenced by market forces. Penal policy has become an arena immersed with commercial businesses such as private prisons (in the US) and corporations offering security. These firms have invested capital, but they have also vested interests in the market for control. They run by the impulse to earn money. More demand for security and control means more turnover, and more turnover means more money.

Christie goes into great detail in describing the emergence and influence of commercial enterprises in the control sector. The claim is not that the penal sector is entirely transformed by marketization. The argument is that it is influenced by the rationality of markets. And this is the development that lies behind Christie's choice of title.

The title indicates that crime control has become an arena for industrial rationality. In this rationality, crime and control appears not as something given, but something that can be won. It is common sense that private enterprises works hard to widen their markets. So does enterprises in the control industry; they look upon crime and control as resources to expand their businesses. In this pursuit they put in quite some political pressure too. The political processes become skewed and goals of penal policies are disturbed. The traditional virtues of penal policy is justice. In the landscape Christie draws up, this is muddled by economic efficiency and financial interests. 
When Christie makes this analytical turn, he also develops his sociological analysis. In Limits he outlines his sociology of proximity, and this lies as a foundation for the thinking in Crime control too. But when he introduces the phrase "crime as a resource « he adds another dimension. Crime as resource is, typically of Christie, an innocuous claim. It is presented in his usual mundane style. But the underlying analysis is everything but simple and its implications are a barrier for the impulse to punish.

Seeing crime as a resource builds on the insight from 1982 that punishment does not mirror actual occurrence. Here the argument is upgraded. Crime rates and rates of imprisonment is more than results of choices, it has become vulnerable to industrial mechanisms.

These words were meant by Christie to be a warning. He disregarded the traditional opposition between the east and the west. He showed that a liberal society can produce just as much, even more punishment, that totalitarian ones. Furthermore, he put the mechanisms that lead to such miserable state of affairs on display. And this makes the translation of his works into Georgian, even more welcome. There are hardly any countries more friendly toward the US in Asia, than Georgia. Friendship is a undisputable good, but it should, in Christies view, not result in blind adaptions of penal policies.

\section{Small words for big issues}

Both books presented here have become classics in criminology. Crime control was republished by Routledge in 2017, with a foreword by probably the most respected criminologist in the English-speaking world, David Garland. I have attempted to situate them in the context of his academic project. The lesson from the great war, was to prevent Holocaust from happening again. Christies contribution to this was to prevent societies to increase social distance. The sociological basis for this program is found in a book first published in 1975, »How tight knit a society?« (1982). This book however, is not translated. Its ideas are spread all over his authorship, perhaps most visibly for an English reading audience, in »Beyond loneliness and institutions (2007, originally 1989). In this book, the importance of proximity is brought to the forefront and his vision of "small is beautiful« is most evident.

Christies book are written in an accessible language. His way of writing was an integral part of his authorship. His last book addressed this issue directly (2009). This choice may lead to the misunderstanding that his books are not sociologically »deep», and perhaps make readers think that they can read them quickly. That would be a mistake.

On a personal note I would add that it also makes it difficult to disagree and discuss with the books. But such issues must be left for later occasions. I will end this presentation by making his words from the introduction of Limits mine: 
The danger with it is that it can be read too fast. The reader gets through it but not into it.

This is true for all the books commented on here. In fact, it goes for his entire authorship.

Kontaktoplysninger

Nicolay B. Johansen: nicolay.b.johansen@modusacademicus.no

\section{References}

Baumann, Z (1989). Modernity and Holocaust. Cornell University Press.

Christie, N (1972). Fangevoktere i konsentrasjonsleire (Prison guards in concentration camps). Universitetsforlaget, Oslo. (Originally published in 1952.)

Christie, N (1977). Conflict as property. British Journal of Criminology, 17(1), 1-14.

Christie, N. (1978). Særreaksjonenes siste skanse . I Christie, N. 1978). Som folk flest. Artikler. Oslo, Universitetsforlaget.

Christie, N (1982b). Hvor tett et samfunn? Oslo, Universitetsforlaget.

Christie, N (1982). Limits to pain. Wipf and Stock.

Christie, N (1997). Crime Control as Industry - Towards Gulags, Western Style. London, Routledge.

Christie, N (2007). Beyond loneliness and institutions. Wipf and Stock; Reprint edition.

Christie, N (2009). Små ord for store spørsmål. Oslo, Universitetsforlaget.

Dahl, R (2007). The BFG. London, Puffin Books.

Flaatten, S (2014). Linedanserne - Straffens strateger og det legale herredømme. Jussens Venner 49(1).

Halvorsen, V (2014). Nils Christie: Conflict as Property. In Dubber M. M. (ed). Foundational Texts in Modern Criminal Law. Oxford.

Hauge, R (2007): On the demise of the Norwegian Vagrancy Act. In On the margins: Nordic alcohol and drug treatment 1885-2007, NAD-publication no. 50.

Mathiesen, T (2016). The Politics of Abolition revisited. Routledge.

Østerberg, D (1999). Det Moderne. Oslo, Pax forlag. 